DOI: 10.15290/aipan.2020.06

\title{
Niewygodni, niewidoczni i niechciani \\ - formy wiktymizacji osób z autyzmem
}

\author{
Emilia Płońska \\ Uniwersytet w Białymstoku \\ emiliaplonska@interia.pl \\ ORCID: https://orcid.org/0000-0001-5704-2445
}

\section{Wprowadzenie}

Formalnie dzieci oraz osoby dorosłe $\mathrm{z}$ autyzmem mają szeroko zagwarantowane prawa: jako obywatele, jako dzieci, jako osoby niepełnosprawne. Każde dziecko w Polsce, również dziecko z autyzmem, ma prawo do nauki, wychowania, opieki odpowiednich do wieku i poziomu rozwoju. Gwarantuje mu to Konstytucja RP oraz Konwencja o Prawach Dziecka. Mówiąc o edukacji osób z autyzmem warto odwołać się do Konwencji o prawach osób z niepełnosprawnościami. Art. 24 wskazanej konwencji gwarantuje uznanie prawa osób niepełnosprawnych do edukacji, na zasadach równych szans $z$ osobami bez niepełnosprawności. Ów przepis stanowi, że podstawową formą edukacji osób z niepełnosprawnościami powinna być edukacja włączająca. Aby wesprzeć realizację tego prawa, Państwa Strony powinny podjąć odpowiednie środki w celu zatrudniania nauczycieli, mających odpowiednie kwalifikacje oraz w celu szkolenia specjalistów i personelu pracujących na wszystkich szczeblach edukacji obejmujących wiedzę na temat problemów niepełnosprawności i korzystania ze wspomagających (augmentatywnych) i alternatywnych sposobów, środków i form komunikacji, technik i materiałów edukacyjnych, jak również zapewnienia dostępu do powszechnego szkolnictwa wyższego, szkolenia zawodowego, kształcenia dorosłych oraz możliwości uczenia się przez całe życie, bez dyskryminacji i na zasadzie równości $z$ innymi osobami ${ }^{1}$. W praktyce prawa te nie są w pełni respektowane. Dzieci ze spektrum autyzmu, w związku z coraz powszech-

$1 \quad$ Konwencja ONZ o Prawach Osób Niepełnosprawnych została uchwalona przez Zgromadzenie Ogólne Narodów Zjednoczonych 13 grudnia 2006 roku. Polski rząd podpisał ją 20 marca 2007 r., natomiast ratyfika- 
niejszą inkluzją edukacyjną, będą stale powiększającą się grupą uczniów w szkołach ogólnodostępnych, a to z kolei zwiększa ryzyko stania się ofiarą agresji rówieśniczej bądź odrzucenia. Agresja rówieśnicza, w którą zaangażowani są uczniowie autystyczni, może przybierać różne formy: sprawcą jest uczeń (uczniowie) „typowo rozwijający się”, a ofiarą uczeń (uczniowie) autystyczny; sprawcą jest uczeń autystyczny, a ofiarą uczeń „typowo rozwijający się”. Warto zaznaczyć, że agresja rówieśnicza we współczesnych czasach przenosi się także do tzw. nowych mediów (Internet, telefony komórkowe). Ze względu na swoje właściwości - np. interaktywność, możliwość obserwowania wyników własnej działalności itp. - pomagają one osobom autystycznym odnaleźć się w specyficznej sytuacji.

Celem artykułu jest ukazanie różnych form wiktymizacji osób autystycznych i wskazanie możliwości przeciwdziałania temu zjawisku. Podstawowymi metodami badawczymi wykorzystanymi w opracowaniu są: metoda analizy i krytyki piśmiennictwa oraz analiza porównawcza opracowań teoretyczno-empirycznych i specjalistycznych z zakresu literatury przedmiotu ${ }^{2}$. Ochronę dziecka autystycznego przed zagrożeniami zapewnić może właściwe sprawowane kontroli i opieki nad dzieckiem ze strony rodziców, nauczycieli, terapeutów, wykorzystujących w odpowiedni sposób instytucje ochrony prawnej.

W toku badań/analizy została sformułowana następująca teza: niewłaściwy dobór dziecka autystycznego do nieodpowiedniej formy kształcenia powoduje jego wiktymizację lub zwiększa jego podatność wiktymizacyjną.

Do określenia form wiktymizacji posłużono się raportami dotyczącymi wiktymizacji dzieci i młodzieży ${ }^{3}$, a także badaniami zawartymi w literaturze przedmiotu (w tym liczne studia przypadku $)^{4}$. Z uwagi na dynamiczny wzrost zainteresowania

cja Konwencji przez Polskę odbyła się 6 września 2012 r. Tekst Konwencji opublikowany został w Dz.U. z dnia 25 października 2012 r., poz. 1169.

3 Ogólnopolski spis autyzmu. Sytuacja młodzieży i dorosłych z autyzmem w Polsce, red. M. Płatos, Warszawa 2016 - zwany dalej Raportem OSA; Społeczny obraz autyzmu, Komunikat z badań CBOS 2015, nr 47; P. Szymańska, Raport JIM. Dziecko z autyzmem. Dostęp do diagnozy, terapii i edukacji w Polsce, Łódź 2016.

4 M. Sajkowska, Doświadczenia wiktymizacyjne młodych Polaków - raport z badań, „Dziecko Krzywdzone” 2011, nr 2; A. Wojciechowska, A. Gulczyńska, Zachowania seksualne dzieci i młodzieży ze spektrum autyzmu. Wyniki badań pilotażowych, „Interdyscyplinarne Konteksty Pedagogiki Specjalnej” 2017, nr 19; W. Baranowska et al., Przemoc rówieśnicza wobec dzieci ze SPE, materiały pokonferencyjne, Warszawa 2015; K. Zajdel, Relacje interpersonalne dziecka autystycznego w grupie - analiza przypadku, „Wychowanie w Rodzinie” 2015, t. 11: Trajektorie więzi rodziny współczesnej, nr 1; A. Antonik, Nauczyciel wobec trudności związanych z edukacją uczniów z zaburzeniami ze spektrum autyzmu w warunkach szkoły integracyjnej i ogólnodostępnej. Analiza obszarów problemowych, „Studia Edukacyjne” 2015, nr 34; E. Korulska, Funkcjonowanie dzieci z autyzmem w warunkach szkoły ogólnodostępnej, czyli integracja w szkole nieintegracyjnej, „Konteksty Pedagogiczne. Spectrum Autyzmu” 2013, nr 1; P. Plichta, M. Olempska-Wysocka, Narażenie na agresję rówieśniczą niepełnosprawnych uczniów szkół integracyjnych w relacjach nauczycieli wspomagających, „Studia Edukacyjne" 2013, nr 28. 
Niewygodni, niewidoczni i niechciani - formy wiktymizacji osób z autyzmem

autyzmem w badaniach naukowych dokonano subiektywnego wyboru źródeł adekwatnych do specyfiki badanego zagadnienia ${ }^{5}$.

\section{Pojęcie autyzmu}

Autyzm należy do tzw. całościowych zaburzeń rozwoju w klasyfikacji ICD-10, oznaczonych pod numerem F.84 ${ }^{6}$. Całościowe zaburzenie rozwoju zwane spektrum autystycznym stanowi grupę niejednorodną klinicznie, a granica między nimi jest dość płynna i umowna.

Problem związku autyzmu z niepełnosprawnością intelektualną stanowił i wciąż stanowi przedmiot zainteresowania współczesnej psychiatrii i psychologii klinicznej. Pojęcie autyzmu jest mniej stygmatyzujące niż niepełnosprawność intelektualna - rodziny łatwiej akceptują diagnozę autyzmu niż niepełnosprawności intelektualnej, choć autyzm nierzadko współwystępuje z niepełnosprawnością intelektualną, a oba zespoły nozologiczne niejednokrotnie się na siebie nakładają ${ }^{7}$. U 75\% osób autystycznych stwierdzono niepełnosprawność intelektualną. Połowa autystów nie wykształca też mowy. Z kolei u 5\% osób z niepełnosprawnością intelektualną tworzy się autyzm. Jest on też 100 razy częstszy wśród tych osób niż w populacji ogólnej, co oznacza, że osoby z niepełnosprawnością intelektualną obarczone są większym ryzykiem występowania autyzmu. Jedynie $25 \%$ autystów dobrze funkcjonuje pod względem poznawczym i ma iloraz inteligencji większy od $70^{8}$.

W świetle ostatniej klasyfikacji Amerykańskiego Towarzystwa Psychiatrycznego DSM-5 pod pojęciem autyzmu nie kryje się jedna konkretna jednostka chorobowa, lecz wiele zaburzeń. Obecna klasyfikacja DSM-5 wprowadziła kategorię „zaburzeń ze spektrum autyzmu" (ASD) ${ }^{9}$, obejmującą następujące jednostki: zaburzenie autystyczne, zespół Aspergera, dziecięce zaburzenie dezintegracyjne i całościowe zaburzenia rozwojowe niezdiagnozowane inaczej. Samo słowo „spektrum” odnosi się do różnic w prezentacji i nasileniu objawów ${ }^{10}$. Pod pojęciem spektrum autyzmu kryją się osoby z zespołem Aspergera, wysoko funkcjonujące w tzw. normie intelek-

P. Szymańska w Raporcie JIM... (s. 7) wskazuje na wzrost liczby opracowań naukowych zajmujących się specyfiką autyzmu. Raport podaje, że przed 1970 r. liczba publikacji w medycznej bazie danych PubMed wynosiła 409 i systematycznie rosła, uzyskując w latach 2010-2015 liczbę 16991 artykułów naukowych ze słowem kluczowym „autism”.

6 Międzynarodowa Statystyczna Klasyfikacja Chorób i Problemów Zdrowotnych - X Rewizja, t. 1, wyd. 2008, s. 248.

7 Niepełnosprawność intelektualna-etiopatogeneza, epidemiologia, diagnoza, terapia, red. K. Bobińska, T. Pietras, P. Gałecki, Wrocław 2012, s. 260.

8 Ibidem, s. 260

9 J. Pasternak, L. Perenc, M. Radochoński, Podstawy psychopatologii dla pedagogów, Rzeszów 2017, s. 4547; Kryteria diagnostyczne zaburzeń psychicznych DSM-5, red. P. Gałecki et al., Wrocław 2018.

10 A. Szafrańska, Uczeń z autyzmem wysoko funkcjonującym w szkole - studium przypadku, „Niepełnosprawność - Zagadnienia, Problemy, Rozwiązania" 2017, nr 3. 
tualnej, jak i osoby z niepełnosprawnościami, przy czym niepełnosprawność intelektualna jest dodatkowym zaburzeniem nakładającym się na autyzm ${ }^{11}$.

Pojęcie autyzmu traktowane jako spektrum zaburzeń oznacza, że populacja osób nimi dotkniętych wykazuje deficyty w trzech wspólnych obszarach funkcjonowania: interakcji społecznych, komunikowania się oraz nietypowych wzorców zachowań i zainteresowań. To grupa bardzo zróżnicowana ze względu na stopień ekspresji deficytów w każdym z tych obszarów. W spektrum autyzmu znajdzie się więc osoba mogąca mieć głębokie upośledzenie umysłowe, brak wykształconych umiejętności mowy i wymagająca stałej opieki w zamkniętym zakładzie specjalnym, jak też osoba o przeciętnej lub nawet wybitnej inteligencji, prawidłowo funkcjonująca społecznie, samodzielna i wykazująca ledwo widoczne zaburzenia w opisanych wcześniej obszarach funkcjonowania.

Mówiąc o osobach autystycznych, nie należy zapominać o osobach z zespołem Aspergera, u których niepełnosprawność intelektualna rozwija się rzadko, a po osiągnięciu dojrzałości zazwyczaj prowadzą one normalne życie społeczne. Jedynym objawem tego zespołu jest deficyt kontaktów społecznych. Literatura określa ich mianem wysokofunkcjonujących osób autystycznych ${ }^{12}$.

Mimo swojej ponad 60-letniej historii (w 1943 r. amerykański psychiatra Leo Kanner jako pierwszy wykonał kliniczny opis zaburzeń autystycznych całościowo jako zespołu i nadał im taki termin) autyzm w dalszym ciągu stanowi wyzwanie dla nauki, a podejmowane prace badawcze wcale nie rozwiązują sporów na jego temat, chociaż przybliżają do zrozumienia jego istoty. Niejasności dotyczą zagadnień związanych z określeniem granic autyzmu, ustaleniem jego istoty czy też wyjaśnieniem jego przyczyn ${ }^{13}$.

\section{Pojęcie wiktymizacji}

Wiktymizacja oznacza pokrzywdzenie, czyli doznanie krzywd i szkód w wyniku jakiegoś zdarzenia ${ }^{14}$. Sytuacja doświadczania przemocy jest mechanizmem stawania się ofiarą tej przemocy, pewnym procesem wchodzenia w rolę ofiary. Proces ten rozpoczyna się $\mathrm{w}$ momencie zaistnienia przemocy, nie kończy się jednak

\footnotetext{
11 J. Buława-Halasz, Rehabilitacja społeczna i zawodowa dorosłych osób autystycznych. Studium fenomenograficzne z zastosowaniem teorii społecznej Pierre'a Bourdieu, Kraków 2017, s. 35-40.

12 Określenie ,jednostki wysokofunkcjonujace” (ang. high-functioning) definiuje się różnie - zwykle opisuje ono osoby o przeciętnej inteligencji i dobrych umiejętnościach językowych; funkcjonuje w słowniku terapeutów, a w literaturze bywa stosowane zarówno w odniesieniu do osób autystycznych, jak i ze zdiagnozowanym zespołem Aspergera; zob. S. Ozonoff, G. Dawson, J.C. McPartland, Wysokofunkcjonujące dzieci ze spektrum autyzmu. Poradnik dla rodziców, Kraków 2015, s. 17-21.

13 K. Kopica, Stereotypy społeczne wobec dzieci z autyzmem, [w:] Dziecko z autyzmem wyzwaniem dla współczesnej szkoły, red. K. Barłóg, Rzeszów 2017, s. 166-167.

14 J.W. Wójcik, Kryminologia. Współczesne aspekty, Warszawa 2014, s. 321.
} 
Niewygodni, niewidoczni i niechciani - formy wiktymizacji osób z autyzmem

z chwilą jej ustania i powoduje nieodwracalne zmiany osobowościowe. O stopniu ryzyka doznania wiktymizacji decydują posiadane określone cechy osobiste, czyli tzw. podatność wiktymologiczna/wiktymogenna/wiktymizacyjna ${ }^{15}$. Na jej zwiększenie mają wpływ czynniki zewnętrzne, znajdujące się poza jednostką, oraz jej indywidualne właściwości psychiczne ${ }^{16}$. Czynniki wpływające na zwiększenie podatności wiktymizacyjnej osób autystycznych to z pewnością: 1) obecność niepełnosprawności zwiększająca prawdopodobieństwo/ryzyko nadużyć na wielu polach; 2) nierozpoznawanie aktów seksualnych jako obraźliwych, powodujące umniejszanie wpływu nadużyć lub całkowite zaprzeczanie/wypieranie; 3) przebywanie w instytucjach pozostających poza kontrolą rodziny pod opieką innych osób.

\section{Formy wiktymizacji osób autystycznych}

Na podstawie raportu Moniki Sajkowskiej ${ }^{17}$ w badanych próbach młodych ludzi w wieku 15-18 lat, przeprowadzonych przez agencję Gemius Polska w 2009 i 2010 r., najczęściej doświadczane formy wiktymizacji to:

- przemoc werbalna i poniżanie,

- zniszczenie rzeczy,

- przemoc rówieśnicza, fizyczna,

- przemoc fizyczna w rodzinie,

- kradziéz,

- molestowanie werbalne (zranienie uczuć mówieniem lub pisaniem rzeczy związanych z seksem dotyczących respondenta, jego zachowań, ciała),

- napad,

- znęcanie się,

- rozbój,

- dotykanie,

- przemoc na randce,

- werbowanie w internecie,

- ekshibicjonizm,

- współżycie seksualne / gwałt.

$\mathrm{Z}$ raportu wynika również, że połowa badanych deklaruje, iż osoby dorosłe krzyczały na nie, wyzywały i poniżały. Co piąty nastolatek został co najmniej raz

\footnotetext{
15 Pojęcie to w literaturze przybiera różne formy: „podatność wiktymologiczna” występuje u J.W. Wójcika, Kryminologia..., s. 320; „podatność wiktymogenna” pojawia się u B. Hołysta, Wiktymologia, Warszawa 2000, s. 82-96 oraz J. Błachut, A. Gaberlego, K. Krajewskiego, Kryminologia, Gdańsk 2004, s.448-450. Natomiast „podatność wiktymizacyjna” jest nowszym pojęciem, występującym m.in. u A. Opar, Podatność wiktymizacyjna - przesłanki i formy przeciwdziałania wiktymizacji, „Rozprawy Społeczne” 2016, nr 2, s. 24-30.

16 N. Mirska, Podatność wiktymizacyjna a samoocena i optymizm, „Bezpieczeństwo. Teoria i Praktyka” 2009, nr 1-2, s. 138.

17 M. Sajkowska, Doświadczenia wiktymizacyjne..., s. 82-83.
} 
uderzony przez dorosłego. Sprawcami przemocy - zarówno fizycznej, jak i psychicznej wobec badanych - byli najczęściej członkowie rodziny, ale i nauczyciele, gdyż co czwarty młody człowiek był poniżająco traktowany w szkole, co dziesiąty doświadczył ze strony personelu szkoły przemocy fizycznej. $8 \%$ badanych co najmniej raz było świadkiem przemocy fizycznej pomiędzy dorosłymi członkami swojej rodziny ${ }^{18}$. Złego traktowania doświadczali badani także ze strony kolegów ze szkoły $(76 \%)^{19}$. Psychicznego znęcania się doświadczało $12 \%$ młodych ludzi. Propozycje o charakterze seksualnym czy też wulgarne komentowanie wyglądu usłyszało $19 \%$ respondentów, $10 \%$ - wielokrotnie ${ }^{20}$.

Powyższy raport nie dotyczy bezpośrednio osób autystycznych, ale jest istotny ze względu na zawartą w nim szczegółowość form wiktymizacji. Analiza literatury (w szczególności studiów przypadku) wskazuje zbieżność tych form wiktymizacji z doznawanymi przez osoby autystyczne. Charakterystyczne dla autystów formy wiktymizacji, opisywane $\mathrm{w}$ licznych opracowaniach $\mathrm{z}$ zakresu literatury przedmiotu, to:

- przemoc ze strony dorosłych,

- naruszenie prawa własności,

- przemoc fizyczna ze strony rówieśników,

- molestowanie werbalne,

- dotykanie intymnych części ciała,

- zmuszanie do oglądania zachowań ekshibicjonistycznch, np. oglądania czyichś intymnych części ciała,

- gwalt,

- werbowanie w internecie (nie znajdując uznania wśród rówieśników, autysta szuka kontaktów w internecie i się zatraca - skutki takie same jak dla każdego innego potencjalnego użytkownika Internetu).

Problem z ustaleniem form wiktymizacji danej osoby autystycznej wynika z faktu, że w większości przypadków to rodzic jest jedynym źródłem informacji o dziecku, a badania na temat problemów osób autystycznych opierają się głównie na wywiadach $z$ rodzicami ${ }^{21}$, opiekunami, terapeutami (również sprawcami przestępstw). Stąd też możemy mówić jedynie o zjawisku, które nie jest w wystarczającym stopniu potwierdzone badaniami z powodu braku odpowiednich narzędzi. Większość badań to badania amerykańskie (dłuższe doświadczenia w tym zakresie). Z polskiego raportu OSA z 2016 r. wynika, że doświadczenia osób autystycznych z bycia ofiarą różnych form przemocy fizycznej, słownej oraz relacyjnej 
Niewygodni, niewidoczni i niechciani - formy wiktymizacji osób z autyzmem

(w tym unikania kontaktu, obgadywania, nakłaniania do zrobienia czegoś nieodpowiedniego i wykorzystywania, np. przez częste pożyczanie rzeczy lub pieniędzy) ze strony kolegów lub koleżanek ze szkoły wykazywało blisko 38\% uczniów z autyzmem, przyznających, że spotkała ich co najmniej jedna $z$ dwóch form przemocy fizycznej: 27\% uczniów raportowało, że „czasem” lub „często” było ofiarami przemocy fizycznej nakierowanej bezpośrednio na nich (np. bicia, kopania). Z kolei 22\% uczniów $z$ autyzmem doświadczyło regularnego niszczenia lub zabierania rzeczy ${ }^{22}$.

Jedna trzecia (33\%) uczniów z autyzmem była regularnie nakłaniana do zrobienia lub powiedzenia czegoś nieodpowiedniego (otwarte zmuszanie, manipulowanie drugą osobą w taki sposób, by nieumyślnie naraziła się na pośmiewisko lub karę). Aż 63\% uczniów z autyzmem stwierdziło, że „czasem” lub „często” koledzy lub koleżanki ze szkoły unikali kontaktu z nimi albo nie zwracali na nich uwagi. Ogółem z raportu wynika, że aż 90\% uczniów z autyzmem doświadczyło przynajmniej jednej formy nękania, $64 \%$ było ofiarami przynajmniej trzech różnych form nękania. Najczęściej było to wyśmiewanie się i przezywanie lub unikanie kontaktu. Uczniowie $\mathrm{z}$ autyzmem są od półtora do dwóch razy bardziej narażeni na nękanie w szkole niż ich rówieśnicy, a szczególnie alarmujące są wyniki dotyczące agresji fizycznej, której doświadczyła ponad jedna czwarta badanych uczniów z autyzmem ${ }^{23}$.

Bezradność i osamotnienie osób autystycznych wobec form przemocy powoduje dość pesymistyczną ocenę możliwości otrzymania pomocy. Warto zauważyć, że długotrwała wiktymizacja, będąca procesem, może spowodować, iż z bycia ofiarą osoba autystyczna może stać się sprawcą.

Zachowania agresywne lub autoagresywne w grupie rówieśniczej wykazywane przez autystów są wynikiem: 1) obezwładniającego lęku będącego wynikiem niestałości otoczenia i niezrozumienia jego potrzeb; 2) deficytów sensorycznych, potrzeby zachowania stałości otoczenia i jednoznaczności komunikacyjnej; 3) problemu z mentalizowaniem (zaburzenia teorii umysłu - brak zrozumienia prostych komunikatów i ich interpretacji). Jeżeli zachowania te w toku terapii nie zostaną zniwelowane, wyciszone (np. poprzez poczucie stałości i rytm dnia), wówczas przybierają na sile i dziecko staje się agresywne.

Dziecko autystyczne doznające długotrwałej wiktymizacji lub multiwiktymizacji $^{24}$ (czyli bycia ofiarą wielu form krzywdzenia, np. wykorzystania seksualnego, przemocy ze strony dorosłych, zaniedbania, przemocy rówieśniczej oraz bycia świadkiem przemocy, a nie wielokrotnego doznawania jednej formy) może stać się również sprawcą przemocy.

24 M. Sajkowska, Doświadczenia wiktymizacyjne..., s. 93-94. 


\section{Środowisko szkolne jako czynnik wpływający na zwiększenie podatności wiktymizacyjnej osób autystycznych}

Oprócz podjętej wcześnie terapii dziecko autystyczne wymaga odpowiedniego środowiska edukacyjnego.

Podstawowym aktem prawnym, któremu podporządkowany jest system oświaty w zakresie wspomagania ucznia z SPE (specjalnymi potrzebami edukacyjnymi) lub autyzmem jest m.in. ustawa $\mathrm{z}$ dnia 7 września 1991 r. o systemie oświaty ${ }^{25}$ oraz ustawa $\mathrm{z}$ dnia 14 grudnia 2016 r. - Prawo oświatowe ${ }^{26}$, zapewniające możliwość pobierania nauki we wszystkich typach szkół przez dzieci i młodzież niepełnosprawną oraz niedostosowaną społecznie, zgodnie $z$ indywidualnymi potrzebami rozwojowymi i edukacyjnymi oraz predyspozycjami, jak również dostęp do edukacji włączającej na wszystkich etapach edukacji.

Rozporządzenie Ministra Edukacji Narodowej z dnia 9 sierpnia 2017 r. w sprawie warunków organizowania kształcenia, wychowania i opieki dla dzieci i młodzieży niepełnosprawnych, niedostosowanych społecznie i zagrożonych niedostosowaniem społecznym ${ }^{27} \mathrm{w} \$ 2.1$. wymienia szczegółowo przedszkola, szkoły i placówki, w których może być realizowane kształcenie, wychowanie i opieka dla dzieci i młodzieży z niepełnosprawnością. Uczniowie ci mogą realizować kształcenie specjalne w placówkach specjalnych, integracyjnych lub ogólnodostępnych, $\mathrm{w}$ ramach edukacji włączającej.

Rozporządzenie Ministra Edukacji Narodowej z dnia 7 września 2017 r. w sprawie orzeczeń i opinii wydawanych przez zespoły orzekające działające w publicznych poradniach psychologiczno-pedagogicznych ${ }^{28} \mathrm{w} \$ 3.4$. wskazuje, że orzeczenia i opinie dla dzieci oraz uczniów niesłyszących, słabosłyszących, niewidomych, słabowidzących i z autyzmem, w tym z zespołem Aspergera, wydają zespoły działające w poradniach wskazanych przez kuratora oświaty, za zgodą organów prowadzących te poradnie.

25 Ustawa z dnia 7 września 1991 r. o systemie oświaty (Dz.U. z 1991 r. Nr 95, poz. 425).

26 Ustawa z dnia 14 grudnia 2016 r. - Prawo oświatowe (Dz.U. z 2018 r. poz. 996).

27 Rozporządzenie Ministra Edukacji Narodowej z dnia 9 sierpnia 2017 r. w sprawie warunków organizowania kształcenia, wychowania i opieki dla dzieci i młodzieży niepełnosprawnych, niedostosowanych społecznie i zagrożonych niedostosowaniem społecznym (Dz.U. z 2017 r. poz. 1578).

28 Rozporządzenie Ministra Edukacji Narodowej z dnia 7 września 2017 r. w sprawie orzeczeń i opinii wydawanych przez zespoły orzekające działające w publicznych poradniach psychologiczno-pedagogicznych (Dz.U. z 2017 r. poz. 1743). 
Niewygodni, niewidoczni i niechciani - formy wiktymizacji osób z autyzmem

Dyskusja na temat optymalnego systemu kształcenia dzieci z niepełnosprawnościami, $w$ tym $\mathrm{z}$ autyzmem, toczy się od lat ${ }^{29} \mathrm{i}$ dotyczy głównie oceny tzw. rozwiązań segregacyjnych i niesegregacyjnych, jak i ich jednoznacznej klasyfikacji ${ }^{30}$.

Do systemu segregacyjnego zalicza się szkoły specjalne, z kolei system niesegregacyjny to zwykłe klasy w szkole ogólnodostępnej, klasy/szkoły integracyjne oraz klasy specjalne w szkołach ogólnodostępnych.

Zgodnie z raportem opublikowanym w 2016 r. przez Fundację JiM (432 badań ankietowych $\mathrm{z}$ udziałem rodziców dzieci z zaburzeniami spektrum autyzmu ze wszystkich województw) „51\% osób z zespołem Aspergera uczęszcza do szkół masowych. W przypadku autyzmu jedynie co piąte dziecko uczy się placówce masowej, natomiast 47\% korzysta z zajęć w placówkach specjalnych (...), najczęściej zajęcia dla osób z zaburzeniami ze spektrum autyzmu są prowadzone w klasie - zarówno w przypadku autyzmu (71\%), jak i zespołu Aspergera (83\%). Co 10 osoba z zaburzeniami ze spektrum autyzmu (zarówno z autyzmem jak i zespołem Aspergera) korzysta $z$ nauczania indywidualnego" 31 .

Wybór placówki edukacyjnej jest częstym dylematem rodziców dziecka autystycznego. Pomocą bywa wydane przez poradnie pedagogiczno-psychologiczne orzeczenie o potrzebie kształcenia specjalnego lub nauczania indywidualnego. Orzeczenie takie stwarza rodzicom i nauczycielom możliwości dostosowania treści, metod i organizacji nauczania do potrzeb i możliwości psychofizycznych dziecka. Ze względu na podkreślaną wielokrotnie różnorodność objawów autyzmu uczniowie ze stwierdzonymi zaburzeniami ze spektrum autyzmu mogą realizować obowiązek przedszkolny i szkolny w różnych placówkach dydaktycznych, a są to: 1) przedszkola i szkoły ogólnodostępne; 2) przedszkola specjalne i oddziały specjalne w przedszkolach ogólnodostępnych; 3) oddziały integracyjne (oddział szkolny, w którym uczniowie posiadający orzeczenie o potrzebie kształcenia specjalnego uczą się i wychowują razem z pozostałymi uczniami o rozwoju przebiegającym prawidłowo); 4) szkoły integracyjne (szkoły, których wszystkie oddziały są oddziałami integracyjnymi); 5) nauczanie indywidualne w domu lub na terenie szkoły. Dysponując opiniami i orzeczeniami, każdy nauczyciel lub terapeuta powinien przeprowadzić diagnozę funkcjonalną ucznia chociażby dlatego, aby prawidłowo skonstruować indywidualny program edukacyjno-terapeutyczny, poznać osobiście zarówno

Zob. Pedagogika specjalna w reformowanym ustroju edukacyjnym, red. Z. Palak, Lublin 2001; Terapia i edukacja osób z autyzmem. Wybrane zagadnienia, red. D. Danielewicz, E. Pisula, Warszawa 2003; A. Masierak-Baran, Różne oblicza integracji, „Rewalidacja” 2010, nr 1, s. 16-28; Dydaktyka specjalna: wybrane zagadnienia, red. J. Wyczesany, Gdańsk 2014.

30 Zob. G. Szumski, Integracyjne kształcenie niepełnosprawnych. Sens i granice zmiany edukacyjnej, Warszawa 2006; A. Firkowska-Mankiewicz, G. Szumski, Wokół edukacji włączającej, Warszawa 2010.

31 P. Szymańska, Raport JIM..., s. 34-35. 
mocne strony, uzdolnienia i zainteresowania, jak i ograniczenia dziecka, ustalić tok postępowania wychowawczo-edukacyjnego.

Każdy typ przedszkola, szkoły posiada swoją specyfikę związaną z organizacją nauczania. Najmniej przygotowane do pracy z uczniami z niepełnosprawnością, $\mathrm{w}$ tym $\mathrm{z}$ autyzmem, są szkoły ogólnodostępne, zobowiązane do zapewnienia opieki i nauki dostosowanej do potrzeb dziecka autystycznego. Najczęściej mają tu organizowane nauczanie indywidualne, obejmujące również dzieci i młodzież, których stan zdrowia uniemożliwia lub znacznie utrudnia uczęszczanie do szkoły. Nauczanie indywidualne może być prowadzone na terenie szkoły lub w warunkach domowych.

Szkoły integracyjne zapewniają uczniom autystycznym integrację ze zdrowymi rówieśnikami. Klasy są tu mniej liczne - od 15 do 20 uczniów, w tym od 3 do 5 uczniów z niepełnosprawnością. W oddziale takim pracuje również dwóch nauczycieli - jeden $\mathrm{z}$ nich musi być pedagogiem specjalnym pracującym z uczniami z niepełnosprawnością. W klasach integracyjnych może być zatrudniona także osoba, która jest pomocą nauczyciela (nie musi mieć wykształcenia pedagogicznego). W szkołach integracyjnych oprócz zajęć edukacyjnych dzieci autystyczne powinny mieć zorganizowane dodatkowe zajęcia usprawniające, terapeutyczne, logopedyczne.

Szkoły specjalne w największym stopniu odpowiadają na potrzeby uczniów $\mathrm{z}$ niepełnosprawnością, gdyż z zasady są tworzone pod kątem potrzeb uczniów z dysfunkcjami rozwojowymi. W Polsce istnieje możliwość organizowania oddziałów dla uczniów z autyzmem. Klasa taka powinna liczyć od 2 do 4 uczniów, a zajęcia w niej powinien prowadzić odpowiednio przygotowany specjalista. Oddziały dla dzieci z autyzmem mogą być tworzone w szkołach ogólnodostępnych i szkołach specjalnych.

W przypadku uczniów z autyzmem obowiązują odrębne plany nauczania, określające ilość obowiązkowych zajęć edukacyjnych oraz zajęć rewalidacyjnych i innych zajęć dodatkowych na każdym etapie nauki, w tym zajęć $\mathrm{z}$ alternatywnych metod komunikacji.

Poziom funkcjonowania społecznego dzieci autystycznych bywa różny. W świetle podziału Lorny Wing i Judith Gould ${ }^{32}$ grupę I stanowią osoby unikające kontaktu (ang. aloof). Cechuje je niechęć do zaangażowania w relacje społeczne, ignorancja komunikatów, wyizolowanie. Grupa II to tzw. grupa pasywna (ang. pas-

32 L. Wing, J. Gould, Severe impairment of social interaction and associated abnormalities in children: epidemiology and classification, „Journal of Autism and Developmental Disorders” 1979, nr 9, s. 11-29. Zob. również A. Lew-Koralewicz, Kompetencje społeczne a funkcjonowanie ucznia z autyzmem w szkole ogólnodostępnej, [w:] Dziecko z autyzmem wyzwaniem dla współczesnej szkoły, red. K. Barłóg, Rzeszów 2017, s. $39-40$. 
Niewygodni, niewidoczni i niechciani - formy wiktymizacji osób z autyzmem

sive) - akceptująca interakcje, ale ich nieinicjująca. III grupa to aktywni, ale dziwni (ang. active but odd) - przejawiający zachowania ekscentryczne, dziwaczne ${ }^{33}$.

Każda grupa społeczna (także szkolna) funkcjonuje w oparciu o formalne, jak i nieformalne struktury społeczne. Strukturę formalną stanowią ustawy, rozporządzenia statut szkoły, zasady klasowe. Przyswojenia zasad szkolnych można autystę nauczyć. Problem stanowi struktura nieformalna, powstająca na bazie kryterium sympatii, antypatii, wspólnych potrzeb, zainteresowań, uzdolnień. Nieformalne zasady, stojące w sprzeczności z zasadami formalnymi, są dla autysty niezrozumiałe. Nie zbuduje on pozycji w zespole klasowym, dopóki nie zyska akceptacji rówieśników, co w przypadku osób autystycznych bywa niejednokrotnie niewykonalne.

Do najczęściej wskazywanych przeszkód i utrudnień wpływających na wizerunek i postrzeganie oraz pozycję dziecka autystycznego w klasie należą kompetencje komunikacyjne i ograniczenia sensoryczne, do których zaliczyć można m.in.: 1) trudności z przystosowaniem się do zasad panujących w grupie, brak lub wybiórczy kontakt wzrokowy, trudności z nawiązaniem i podtrzymywaniem relacji, izolacja; 2) brak lub ograniczenie umiejętności przewidywania i rozumienia zachowań własnych oraz innych osób, a także konsekwencji tych działań, mylne odczytywanie zachowań, gestów, oczekiwań otoczenia; 3) trudności z rozumiem instrukcji i zasad wyrażanych werbalnie, $\mathrm{z}$ przejmowaniem perspektywy myślowej i intencji innych osób, gwałtowne reakcje na zmiany; 4) przekraczanie granic i zasad panujących w grupie, wyrażanie zachowań nieakceptowanych społecznie ${ }^{34}$; 5) trudności w komunikacji językowej (od całkowicie zaburzonej komunikacji werbalnej do nadwerbalnej, czyli zbyt dosadnego rozumienia języka, patosu, kłopoty z naprzemienną rozmową) ${ }^{35}$, ograniczenia w rozumieniu wszelakich zawiłości językowych, metafor, żartów; 6) hiperaktywność, nadmierna ruchliwość, problemy ze skupieniem uwagi; 7) obniżony lub podwyższony próg reakcji lub wrażliwości na bodźce (dotyk, dźwięki, światło itp.) niepokój; 8) rytuały, schematyzmy, sztywność zachowań.

Podane cechy nie tylko wpływają na trudności w uczestnictwie w nieformalnej strukturze klasowej, ale determinują też czynniki ryzyka odrzucenia rówieśniczego dzieci z autyzmem, na które składają się m.in.: 1) dobrowolne wycofywanie się z grupy, 2) niedostępność, 3) złe zachowanie, 4) niezdolność do współpracy, 5) agresywność, 6) egocentryzm ${ }^{36}$.

Do osiągnięcia korzyści w postaci skorzystania z systemu włączającego czy integracyjnego konieczne jest uzyskanie minimalnego zakresu kompetencji społecznych pozwalających na nawiązanie relacji z rówieśnikami.

\footnotetext{
33 A. Lew-Koralewicz, Kompetencje społeczne..., s. 39-40.

34 E. Pisula, Autyzm. Od badań mózgu do praktyki psychologicznej, Gdańsk 2012.

35 M. Korendo, Językowa interpretacja świata w wypowiedziach osób z zespołem Aspergera, Kraków 2013.

36 A. Lew-Koralewicz, Kompetencje społeczne..., s. 41
} 


\section{Możliwości przeciwdziałania wiktymizacji osób autystycznych}

Z analizy krytycznej literatury oraz raportów wynika niezadowolenie rodziców, jak i nauczycieli z uczestnictwa dziecka w wybranej dla niego formy edukacji. Duża grupa uważa, że dziecko autystyczne więcej może skorzystać, ucząc się w środowisku specjalnym, dostosowanym do niego lepiej niż w szkole ogólnodostępnej. Inni są odmiennego zdania, że środowisko szkoły specjalnej ogranicza możliwości rozwojowe ich dzieci ${ }^{37}$. Niewątpliwie „teatr życia szkolnego” rewiduje wszelkie poglądy na ten temat i jedyną właściwą przesłanką umieszczenia dziecka w odpowiedniej placówce jest kierowanie się jego indywidualnymi predyspozycjami. Niestety, wielu rodziców popełnia ten błąd, że mylnie ocenia możliwości swego dziecka, ale nie bierze również pod uwagę opinii i zdania rodziców innych dzieci szkół integracyjnych i ogólnodostępnych, którzy albo otwarcie deklarują niechęć do dziecka autystycznego, albo pomimo zgłoszeń o widocznych problemach rówieśniczych ignorują ten fakt, składając na barki nauczycieli doprowadzenie do zapewnienia odpowiednich relacji w klasie.

W szkołach specjalnych istnieje mniejsze prawdopodobieństwo narażenia osób autystycznych na wiktymizację (mniejsza podatność wiktymizacyjna). Większa liczba pedagogów specjalnych, mniej liczne grupy, dzieci wyjeżdżające na wspólne turnusy rehabilitacyjne, obozy, wyjazdy integracyjne wspólnie uczestniczą we wszystkich przedsięwzięciach. Zarówno dzieci, jak rodzice znają się bliżej z uwagi na to, że ich dzieci przebywają $\mathrm{w}$ tych placówkach zwykle od początku do końca edukacji (tak długo, jak to możliwe, gdyż brakuje innych placówek). Jest to niewątpliwie społeczność hermetyczna, ściśle skoncentrowana na nauczeniu funkcjonowania dziecka w społeczeństwie, reagująca na przejawy przemocy, zachowania trudne, akceptująca trudności wychowawcze, bo tylko z takimi ma do czynienia.

W szkołach masowych dziecko nieposiadające wypracowanych podstawowych umiejętności społecznych, niekomunikujące się, angażujące w zachowania trudne, nieinteresujące się innymi ludźmi jest bardziej narażone na wiktymizację. Uczeń autystyczny uczestniczy w niektórych zajęciach wspólnie z innymi uczniami, ale w większości przypadków prowadzone jest indywidualne nauczanie (integracja na wybranych przedmiotach - edukacja muzyczna, plastyka, wychowania fizyczne, przerwy). Zdarza się, że nauczyciel wspomagający wyręcza dziecko we wszystkich działaniach, tłumaczy jego trudne zachowania, interweniuje w banalnych sprawach, co budzi powszechny sprzeciw dzieci i przeradza się w obojętność, niechęć, docinki i przemoc. Nauczyciel wspomagający skoncentrowany na swoim uczniu nie jest służącym dziecka, jego piastunką, lecz rodzice zwykle tego od niego oczekują. Fak- 
Niewygodni, niewidoczni i niechciani - formy wiktymizacji osób z autyzmem

tem jest, że dla większości niewyszkolonych nauczycieli kontakt z osobą autystyczną jest źródłem stresu i frustracji ${ }^{38}$.

Szkoły integracyjne posiadają plus w postaci dodatkowego nauczyciela pracującego na tych samych prawach co wychowawca (dwóch nauczycieli z przygotowaniem specjalnym). Działalność dydaktyczno-wychowawcza powinna zaspokajać potrzeby ucznia pełnosprawnego, jak i niepełnosprawnego, co niestety w praktyce często jest niemożliwe lub przybiera karykaturalny obraz kształcenia integracyjnego $^{39}$. W warunkach integracji widoczny bywa brak możliwości dostrzeżenia wiktymizacji. Uczniowie często działają „poza wiedzą nauczycieli” albo nauczyciel udaje, że problemu nie dostrzega ${ }^{40}$.

Nierozwiązanym dotąd problemem pozostaje dylemat, jak w warunkach integracji zorganizować proces dydaktyczno-wychowawczy, aby dać poczucie odrębności dziecku, indywidualności oraz dać poczucie przynależności do klasy i grupy rówieśniczej.

Działania profilaktyczne zmierzające do zmniejszenia ryzyka narażenia dziecka autystycznego na wiktymizację z całą pewnością powinny uwzględniać wczesną interwencję, czyli rozpoczęcie działań profilaktycznych już na etapie przedszkola, poprzez zaufanie specjalistom i terapeutom pracującym z dzieckiem przy wyborze właściwej placówki edukacyjnej na dalszych etapach nauki oraz obserwację dziecka i eliminację w miarę możliwości zachowań trudnych.

Równie istotna jest praca $\mathrm{z}$ dzieckiem nad jego reakcjami, zachowaniami w danej chwili, a nie praca $z$ dokumentami opisującymi problemy dziecka autystycznego występujące w przeszłości. Dokumentacja diagnostyczna, terapeutyczna jest przydatna na etapie poznania dziecka, w późniejszym czasie może okazać się niewystarczająca.

Działania profilaktyczne zmierzające do zmniejszenia ryzyka wiktymizacji dziecka autystycznego na etapie edukacji szkolnej powinny się koncentrować na:

- obserwacji;

- wypracowaniu wspólnych celów i metod pracy z innymi nauczycielami;

- opracowaniu klasowej strategii na rzecz wspierania właściwych postaw społecznych i przeciwdziałania agresji rówieśniczej;

- nawiązaniu współpracy z rodzicami (wymiana informacji, wspólne określenie zasad postępowania w klasie w przypadku wystąpienia zachowań agresywnych wszystkich dzieci).

38 M. Lubas, Uczeń z autyzmem w szkole - na przykładzie Szkoły Podstawowej w Błażowej Dolnej, [w:] Dziecko z autyzmem wyzwaniem dla współczesnej szkoły, red. K. Barłóg, Rzeszów 2017, s. 70-73.

39 K. Zajdel, Relacje interpersonalne dziecka autystycznego w grupie - analiza przypadku, „Wychowanie w Rodzinie" 2015, nr 1, s. 306-317.

$40 \quad$ Ibidem, s. 315. 
Niejednokrotnie problem tkwi $\mathrm{w}$ braku właściwego przepływu informacji, wiedzy rodziców o osobach autystycznych, stąd podstawowym działaniem zapobiegającym wiktymizacji jest rozmowa i informacja. Nikt nie chce być zaskakiwany. Bolączką systemu edukacji jest „wpychanie dzieci” do klas integracyjnych, które mają wypracowane sposoby i metody postępowania w przypadku zachowań problemowych. Każda nowa osoba, która nie dostosowuje się do zasad panujących w klasie, sama staje się ofiarą albo sprawcą przemocy w klasie. Klasy integracyjne lub klasy w szkołach masowych, w których uczą się osoby z niepełnosprawnością, powinny być mocno kontrolowane pod kątem liczebności oraz wymiany klasowej.

Prawidłowa prowadzona edukacja włączająca dzieci z autyzmem powinna uwzględniać: (1) dostosowanie wymagań do indywidualnych potrzeb psychofizycznych i edukacyjnych dzieci i młodzieży z autyzmem, nowoczesną konstrukcję programów kształcenia; (2) zajęcia rewalidacyjne prowadzone przez specjalistów w placówce ogólnodostępnej; (3) odpowiednie pomoce dydaktyczne i wystarczającą liczbę nauczycieli wspierających; (4) opracowanie systemu stwarzającego podstawę szerszego udziału asystentów uczniów $\mathrm{z}$ orzeczoną potrzebą kształcenia specjalnego; (5) opracowanie narzędzi do jakościowej analizy przyczyn i konsekwencji wyboru lub zmiany rodzaju szkoły przez dzieci z autyzmem (zawierające ewentualne czynniki ryzyka wykluczenia z ogólnego nurtu kształcenia); (6) kompleksową opiekę specjalistyczną, zajęcia rewalidacyjne, jak również możliwości zdobycia zawodu zgodnie z osobistymi preferencjami i zainteresowaniami osób $\mathrm{z}$ autyzmem.

Formy pomocy, których będzie potrzebował uczeń z autyzmem to: (1) pomoc terapeutyczna ( $w$ różne formy terapii na terenie szkoły lub poza nią np. w terapii psychologicznej, w zajęciach korekcyjno-kompensacyjnych, w terapii logopedycznej); (2) pomoc dydaktyczno-wychowawcza (stosowanie w toku lekcji metod i sposobów oceniania oraz metod wychowawczych, ułatwiających uczniowi naukę i społeczne przystosowanie); (3) pomoc medyczna (stała opieka lekarza specjalisty, odpowiednie pomoce „techniczne” np. okulary, szkła, odpowiednie leczenie - np. w ośrodku rehabilitacyjnym czy sanatorium); (4) pomoc socjalna.

Poniższa tabela wskazuje, jak właściwie powinna być prowadzona edukacja włączająca dzieci z autyzmem, by można było w ogóle zacząć mówić o jej skuteczności. 
Niewygodni, niewidoczni i niechciani - formy wiktymizacji osób z autyzmem

Tabela 1. Sposoby prowadzenia edukacji włączającej osób z autyzmem

\begin{tabular}{|c|c|}
\hline Błędne sposoby prowadzenia edukacji włączającej & Prawidłowe sposoby prowadzenia edukacji włączającej \\
\hline \begin{tabular}{|l} 
- koncentracja uczuciowa na dziecku \\
- współczucie graniczące z litością \\
- nadmierna pobłażliwość w sytuacjach zadaniowych \\
- nadmierne chronienie dziecka i przez to wyłączanie go \\
z różnych form aktywności \\
- eksponowanie deficytów dziecka \\
- karanie za objawy
\end{tabular} & $\begin{array}{l}\text { - przydzielanie różnych zadań na równi innymi osobami } \\
\text { (jeżeli tylko to możliwe) } \\
\text { - przyznawanie mu różnych znaczących ról na równi } \\
\text { z innymi uczniami } \\
\text { - włączanie we wszystkie zajęcia w toku lekcji i pozalek- } \\
\text { cyjne, w których może brać udział, nawet jeżeli wyma- } \\
\text { ga to indywidualizacji pracy } \\
\text { - wspieranie go zachętą i jawnie wyrażoną wiarą w jego } \\
\text { możliwości radzenia sobie w trudnych sytuacjach } \\
\text { - udzielanie mu różnego rodzaju specjalnej pomocy } \\
\text { z równoczesnym traktowaniem tej pomocy jako natu- } \\
\text { ralnego świadczenia, a nie jako uciążliwego obowiąz- } \\
\text { ku czy jałmużny } \\
\text { - ukazywanie rówieśnikom jego zdolności, osiągnięć, } \\
\text { pozytywnych zachowań, eksponowanie wytworów jego } \\
\text { pracy razem z wytworami innych uczniów } \\
\text { - serdeczne odnoszenie się do niego, próba nawiązywa- } \\
\text { nia z nim więzi emocjonalnej, tak jak z innymi } \\
\text { - tworzenie prawidłowych warunków edukacyjnych dla } \\
\text { ucznia dostosowanie metody i formy pracy z dziec- } \\
\text { kiem do jego możliwości („podążanie za”, holding, tera- } \\
\text { pia behawioralna) } \\
\text { - zapewnienie pomocy asystenta dla ucznia z autyzmem }\end{array}$ \\
\hline
\end{tabular}

Źródło: opracowanie własne

Na jakość edukacji uczniów z autyzmem mają wpływ: (1) czynniki strukturalne (dostosowanie architektoniczne placówek, zapewnienie środków finansowych); (2) czynniki dydaktyczne (wyposażenie placówki w specjalistyczne programy przygotowujące nauczyciela do pracy z dziećmi o zróżnicowanych potrzebach edukacyjnych oraz odpowiednie pomoce dydaktyczne; (3) czynniki personalne (kompetencje miękkie, umiejętność wspierania dzieci z autyzmem, umiejętność rozwiązywania konfliktów, mediacji - rodzinnych i rówieśniczych, umiejętność pracy w grupach niejednorodnych zdrowotnie); (4) dostępność wsparcia szczególnie metodycznego oraz asystenta ucznia z autyzmem; (5) liczebność zespołów klasowych.

\section{Podsumowanie}

Analiza literatury przedmiotu, jak i raportów dotyczących wiktymizacji osób autystycznych potwierdza postawioną wcześniej tezę, iż niewłaściwy dobór dziecka 
autystycznego do nieodpowiedniej formy kształcenia powoduje jego wiktymizację lub zwiększa jego podatność wiktymizacyjną.

Zaobserwowano następujące przyczyny wiktymizacji osób autystycznych:

- działania rówieśnicze: 1) wynikające z postaw rodziców i nauczycieli - prośby rodziców o zabranie ucznia autystycznego ze szkoły; ich niechęć do nauki z dziećmi niepełnosprawnymi; używanie określeń „debil”, „nienormalny” (dzieci bezwiednie przejmują postawę rodziców i nauczycieli i utrwalają stereotypy); 2) wynikające $\mathrm{z}$ postaw samych rówieśników - brak akceptacji, wyśmiewanie się, czynienie z dziecka autystycznego kozła ofiarnego lub klasowego śmieszka, wykorzystywanie łatwowierności dziecka w celach przywłaszczania sobie / chowania dla zabawy cennych sprzętów, które posiada, np. wykorzystywanego do nauki laptopa;

- działania rodziców: 1) nieakceptowanie braku deficytów dziecka i zmuszanie go do funkcjonowania w środowisku szkoły masowej / nauczania integracyjnego pomimo zaleceń terapeutów, lekarzy i wskazania na przykład szkoły specjalnej; 2) roztaczanie niepotrzebnego parasola ochronnego nad dzieckiem i wybór indywidualnego nauczania powodującego zamykanie się ucznia we własnym świecie (przy zdolnościach informatycznych narażanie dziecka na przykład na przestępstwa internetowe);

- działania nauczycieli: 1) wyręczanie ucznia autystycznego. Uczeń wykorzystuje sytuację lub dostosowuje się do niej, przyzwyczaja się lub uzależnia od podpowiedzi i kontroli innych osób. $Z$ drugiej strony nie jest to akceptowane przez rodziców innych uczniów (Internet - wypowiedzi), powodując falę dezaprobaty, ale i zazdrość innych uczniów, poczucie niesprawiedliwości oraz chęć ulgowego traktowania ich samych przez nauczycieli. W tworzącej się nieformalnej strukturze społecznej klasy budzą się w ten sposób konflikty, a przy dłuższym czasie występowania przyczyniają się do wiktymizacji osób autystycznych; 2) nauczyciel wspierający, a nie wyręczający. Obserwowane jest niewłaściwe podejście rodziców do roli nauczycieli wspierających ich dzieci. Oczekiwania rodziców względem nich polegają na uznaniu ich za służących dziecka, wyręczających wychowanków we wszystkich działaniach; 3) brak umiejętności rozwiązywania konfliktów klasowych i unikania konfrontacji, niezauważanie problemów.

Warto podkreślić w tym momencie pewną nieoczywistą prawdę, że wzajemne relacje zależą od właściwego podejścia zarówno uczniów, jak i nauczycieli oraz rodziców. W procesie komunikacji każde jego ogniwo jest tak samo ważne, a interesy różnych osób muszą koncentrować się na jednym kierunku, a nie przypominać wojnę prowadzoną na wszystkich frontach. 
Niewygodni, niewidoczni i niechciani - formy wiktymizacji osób z autyzmem

\section{Akty prawne}

Konwencja ONZ o Prawach Osób Niepełnosprawnych, sporządzona w Nowym Jorku dnia 13 grudnia 2006 r. (Dz.U. z dnia 25 października 2012 r., poz. 1169).

Ustawa z dnia 7 września 1991 r. o systemie oświaty (Dz.U. z 1991 r. Nr 95, poz. 425).

Ustawa z dnia 14 grudnia 2016 r. - Prawo oświatowe (Dz.U. z 2018 r. poz. 996).

Rozporządzenie Ministra Edukacji Narodowej z dnia 9 sierpnia 2017 r. w sprawie warunków organizowania kształcenia, wychowania i opieki dla dzieci i młodzieży niepełnosprawnych, niedostosowanych społecznie i zagrożonych niedostosowaniem społecznym (Dz.U. z 2017 r. poz. 1578).

Rozporządzenie Ministra Edukacji Narodowej z dnia 7 września 2017 r. w sprawie orzeczeń i opinii wydawanych przez zespoły orzekające działające w publicznych poradniach psychologiczno-pedagogicznych (Dz.U. z 2017 r. poz. 1743).

\section{Literatura}

Antonik A., Nauczyciel wobec trudności związanych z edukacją uczniów z zaburzeniami ze spektrum autyzmu $w$ warunkach szkoły integracyjnej i ogólnodostępnej. Analiza obszarów problemowych, „Studia Edukacyjne” 2015, nr 34.

Apanowicz J., Metodologia ogólna, Gdynia 2002.

Baranowska W. et al., Przemoc rówieśnicza wobec dzieci ze SPE, materiały pokonferencyjne, Warszawa 2015.

Błachut J., Gaberle A., Krajewski K., Kryminologia, Gdańsk 2004.

Buława-Halasz J., Rehabilitacja społeczna i zawodowa dorosłych osób autystycznych. Studium fenomenograficzne z zastosowaniem teorii społecznej Pierre’a Bourdieu, Kraków 2017.

Dydaktyka specjalna: wybrane zagadnienia, red. J. Wyczesany, Gdańsk 2014.

Firkowska-Mankiewicz A., Szumski G., Wokół edukacji włączajacej, Warszawa 2010.

Hołyst B., Wiktymologia, Warszawa 2000.

Kopica K., Stereotypy społeczne wobec dzieci z autyzmem, [w:] Dziecko z autyzmem wyzwaniem dla współczesnej szkoły, red. K. Barłóg, Rzeszów 2017.

Korendo M., Językowa interpretacja świata $w$ wypowiedziach osób z zespołem Aspergera, Kraków 2013.

Korulska E., Funkcjonowanie dzieci z autyzmem w warunkach szkoły ogólnodostępnej, czyli integracja w szkole nieintegracyjnej, „Konteksty Pedagogiczne. Spectrum Autyzmu" 2013, nr 1.

Kryteria diagnostyczne zaburzeń psychicznych DSM-5, red. P. Gałecki et al., Wrocław 2018.

Lew-Koralewicz A., Kompetencje społeczne a funkcjonowanie ucznia $z$ autyzmem $w$ szkole ogólnodostępnej, [w:] Dziecko z autyzmem wyzwaniem dla współczesnej szkoły, red. K. Barłóg, Rzeszów 2017. 
Lubas M., Uczeń z autyzmem w szkole - na przykładzie Szkoły Podstawowej w Błażowej Dolnej, [w:] Dziecko z autyzmem wyzwaniem dla współczesnej szkoły, red. K. Barłóg, Rzeszów 2017.

Masierak-Baran A., Różne oblicza integracji, „Rewalidacja” 2010, nr 1.

Międzynarodowa Statystyczna Klasyfikacja Chorób i Problemów Zdrowotnych - X Rewizja, t. 1, wydanie 2008 .

Mirska N., Podatność wiktymizacyjna a samoocena i optymizm, „Bezpieczeństwo. Teoria i Praktyka" 2009, nr 1-2.

Niepełnosprawność intelektualna - etiopatogeneza, epidemiologia, diagnoza, terapia, red. K. Bobińska, T. Pietras, P. Gałecki, Wrocław 2012.

Ogólnopolski spis autyzmu. Sytuacja młodzieży i dorosłych z autyzmem w Polsce, red. M. Płatos, Warszawa 2016.

Opar A., Podatność wiktymizacyjna - przesłanki i formy przeciwdziałania wiktymizacji, „Rozprawy Społeczne” 2016, nr 2.

Ozonoff S., Dawson G., McPartland J.C., Wysokofunkcjonujące dzieci ze spektrum autyzmu. Poradnik dla rodziców, Kraków 2015.

Pasternak J., Perenc L., Radochoński M., Podstawy psychopatologii dla pedagogów, Rzeszów 2017.

Pedagogika specjalna w reformowanym ustroju edukacyjnym, red. Z. Palak, Lublin 2001.

Pisula E., Autyzm. Od badań mózgu do praktyki psychologicznej, Gdańsk 2012.

Plichta P., Olempska-Wysocka M., Narażenie na agresję rówieśnicza niepełnosprawnych uczniów szkół integracyjnych $w$ relacjach nauczycieli wspomagajacych, „Studia Edukacyjne" 2013, nr 28.

Sajkowska M., Doświadczenia wiktymizacyjne młodych Polaków - raport z badań, „Dziecko Krzywdzone" 2011, nr 2.

Społeczny obraz autyzmu, Komunikat z badań CBOS 2015, nr 47.

Szafrańska A., Uczeń z autyzmem wysoko funkcjonującym w szkole - studium przypadku, „Niepełnosprawność - Zagadnienia, Problemy, Rozwiązania” 2017, nr 3.

Szumski G., Integracyjne kształcenie niepetnosprawnych. Sens i granice zmiany edukacyjnej, Warszawa 2006.

Szymańska P., Raport JIM. Dziecko z autyzmem. Dostęp do diagnozy, terapii i edukacji w Polsce, Łódź 2016.

Terapia i edukacja osób z autyzmem. Wybrane zagadnienia, red. D. Danielewicz, E. Pisula, Warszawa 2003.

Wing L., Gould J., Severe impairment of social interaction and associated abnormalities in children: epidemiology and classification, „Journal of Autism and Developmental Disorders" 1979, nr 9.

Wojciechowska A., Gulczyńska A., Zachowania seksualne dzieci i młodzieży ze spektrum autyzmu. Wyniki badań pilotażowych, „Interdyscyplinarne Konteksty Pedagogiki Specjalnej” 2017, nr 19. 
Niewygodni, niewidoczni i niechciani - formy wiktymizacji osób z autyzmem

Wójcik J.W., Kryminologia. Współczesne aspekty, Warszawa 2014.

Zajdel K., Relacje interpersonalne dziecka autystycznego w grupie - analiza przypadku, „Wychowanie w Rodzinie" 2015, nr 1.

Zamkowska A., Postawy rodziców wobec edukacji włączającej w badaniach międzynarodowych, „Niepełnosprawność. Dyskursy Pedagogiki Specjalnej” 2019, nr 33. 